\title{
Proteomic and peptidomic study of proteolysis in quarter milk after infusion with lipoteichoic acid from Staphylococcus aureus
}

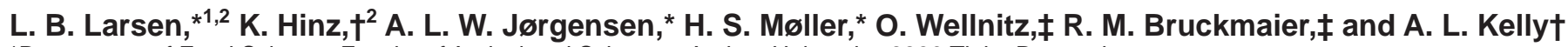 \\ *Department of Food Science, Faculty of Agricultural Sciences, Aarhus University, 8830 Tjele, Denmark \\ †School of Food and Nutritional Sciences, University College Cork, Ireland \\ $\ddagger$ Veterinary Physiology, Vetsuisse Faculty, University of Bern, Switzerland
}

\begin{abstract}
Mastitic milk is associated with increased bovine protease activity, such as that from plasmin and somatic cell enzymes, which cause proteolysis of the caseins and may reduce cheese yield and quality. The aim of this work was to characterize the peptide profile resulting from proteolysis in a model mastitis system and to identify the proteases responsible. One quarter of each of 2 cows (A and B) was infused with lipoteichoic acid from Staphylococcus aureus. The somatic cell counts of the infused quarters reached a peak $6 \mathrm{~h}$ after infusion, whereas plasmin activity of those quarters also increased, reaching a peak after 48 and $12 \mathrm{~h}$ for cow A and $\mathrm{B}$, respectively. Urea-polyacrylamide gel electrophoretograms of milk samples of cow A and B obtained at different time points after infusion and incubated for up to $7 \mathrm{~d}$ showed almost full hydrolysis of $\beta$ - and $\alpha_{\mathrm{S} 1}$-casein during incubation of milk samples at peak somatic cell counts, with that of $\beta$-casein being faster than that of $\alpha_{\mathrm{S}_{1}}$-casein. Two-dimensional gel electrophoretograms of milk $6 \mathrm{~h}$ after infusion with the toxin confirmed hydrolysis of $\beta$ - and $\alpha_{\mathrm{S1}_{1}}$-casein and the appearance of lower-molecular-weight products. Peptides were subsequently separated by reversed-phase HPLC and handmade nanoscale $\mathrm{C}_{18}$ columns, and identified by matrix-assisted laser desorption/ionization timeof-flight tandem mass spectrometry. Twenty different peptides were identified and shown to originate from $\alpha_{\mathrm{s} 1^{-}}$and $\beta$-casein. Plasmin, cathepsin B and D, elastase, and amino- and carboxypeptidases were suggested as possible responsible proteases based on the peptide cleavage sites. The presumptive activity of amino- and carboxypeptidases is surprising and may indicate the activity of cathepsin $\mathrm{H}$, which has not been reported in milk previously.
\end{abstract}

Key words: bovine milk, peptidomics, proteolysis, somatic cell count

\footnotetext{
Received May 6, 2010

Accepted August 10, 2010.

${ }^{1}$ Corresponding author: lottebach.larsen@agrsci.dk

${ }^{2}$ Contributed equally to this paper.
}

\section{INTRODUCTION}

Mastitis is a major disease in dairy cattle that causes significant economical losses due to decreased milk production, increased veterinary costs, and discarded milk (Everson, 1984; Windig et al., 2005). Mastitis involves inflammation of the mammary gland resulting from the introduction and multiplication of pathogenic microorganisms in the mammary gland. Causative pathogens include Escherichia coli and Staphylococcus aureus (Heringstad et al., 2000; Bradley, 2002). The invasion of bacteria into the mammary gland and the bacteria's multiplication induce the action of the innate mammary gland immune defense system. Somatic cells such as polymorphonuclear leucocytes (PMN) are one of the major cellular immune components that respond to infection; these cells migrate to the site of infection to kill bacteria, resulting in a rapid increase in milk SCC. Milk SCC is thus used to assess inflammation, the health status of the mammary gland, and milk quality.

Polymorphonuclear leucocytes and macrophages, another somatic cell type, respond to bacteria or bacterial products by secreting various substances that mediate the response to the infection (Pugin, 1994; Le Roux et al., 2003; Haddadi et al., 2006). For example, cytokines disrupt the tight junctions between the secretory epithelial cells, which results in increased levels of the principal proteolytic enzyme in milk, plasmin, and its zymogen, plasminogen, in the infected glands. The plasmin system has been widely investigated in normal and mastitic milk (Andrews and Alichanidis, 1983; Pugin, 1994).

Proteases in milk may potentially arise from different sources, for example, secretion into milk from the mammary epithelium, transfer from blood to milk due to a compromised barrier between milk and blood at mastitis, or secretion or leakage from invading microorganisms or from bovine somatic cells (Politis et al., 1989a,b; Haddadi et al., 2006; Larsen et al., 2006). Furthermore, some bacteria secrete activators of protease zymogens, which, in synergy with bovine proenzymes, can increase the proteolytic potential of fresh and stored milk (Jackson et al., 1981; Leigh, 1994; Larson et 
al., 2006). Plasmin is transported into milk from blood as plasminogen and then activated, whereas other proteases in milk are thought to be released from somatic cells. Both neutrophils and macrophages contain active lysosomal acid and neutral proteases, such as cathepsins, procathepsins, and elastase (and protease zymogens; Kirschke and Barrett, 1987; Travis, 1988, Sordillo et al., 1997; Kelly et al., 2006).

Proteolysis of casein thus increases in bovine milk during elevated SCC and mastitis (de Rahm and Andrews, 1982; Andrews, 1983), due both to a direct increase in the level of proteases present (Larsen et al., 2006) and, in some instances, to increased activation of zymogens of proteases, leading to increased enzymatic activities (e.g., of plasminogen; Heegaard et al., 1994). Increased proteolytic activity of milk then decreases levels of casein (Le Roux et al., 1995). Whereas plasmin is the most important protease in milk from healthy cows, nonplasmin proteases become more important with the increasing severity of udder inflammation. Proteolysis of the $\mathrm{CN}$ leads to decreases in $\mathrm{CN}$ proportions, especially $\beta-\mathrm{CN}$ and $\alpha_{\mathrm{S}_{1}} \mathrm{CN}$, with simultaneous clear increases in $\gamma$-CN and proteose peptone levels (Fox and Kelly, 2006). The dairy industry has particular challenges in processing high SCC milk as the proteolysis of casein results, for example, in decreased cheese yields, off-flavor development, and decreased shelf life of dairy products (Ali et al., 1980; de Rahm and Andrews, 1982). Knowledge of the proteases responsible for proteolysis in milk is important as it enables the identification of the enzyme systems that are most detrimental to milk protein quality.

In addition to the characterization of proteases and measurement of enzyme activities, new peptidomic methods using mass spectrometry are now available, by which the actual result of these proteolytic activities in specific milk samples can be studied and characterized. In an earlier study, the peptide profile of 3 different milk types, a normal milk sample, milk with medium SCC (about 500,000 cells/mL), and milk obtained during clinical mastitis after infection with Streptococcus uberis, was studied using liquid chromatography-matrix-assisted laser desorption/ionization (LC-MALDI) spotting and MS detection of peptides (Wedholm et al., 2008). By these methods, a range of peptides corresponding to $\mathrm{CN}$ fragments were identified and, by consulting the AA sequences of $\mathrm{CN}$, cleavage sites were identified and on this basis some potentially responsible proteases were suggested based on earlier reported specificities.

In the absence of bacteria, model infections can be induced by using bacterial antigens to bring about experimental mastitis. In previous studies, cows were infused with gram-negative LPS of E. coli (Andrews,
1983; Moussaoui et al., 2002, 2004; Sládek et al., 2002; Sohn et al., 2007). Another model system uses the bacterial lipoteichoic acid (LTA) of gram-positive Staph. aureus to initiate mastitis (Strandberg et al., 2005). In this study, the inflammatory response of mid-lactation cows to Staph. aureus LTA was investigated. The present study is a further development of this approach, reporting a proteomic and peptidomic study of bovine milk from cows during early immunological response to infusion with bacterial LTA, thereby eliminating the contribution from mastitis bacteria themselves to the proteolytic cascade.

\section{MATERIALS AND METHODS}

\section{Materials}

Acetic acid was purchased from J. T. Baker (Deventer, Holland), acetonitrile from Rathburn Chemicals (Walkerburn, UK), and trifluoroacetic acid (TFA) from Merck (Darmstadt, Germany). Water was purified using a Milli-Q Gradient system (Millipore, Bedford, MA). Buffer solutions for HPLC were filtered through a 0.45- $\mu \mathrm{m}$ Magna nylon filter from Frisenette (Ebeltoft, Denmark) before use. Fluorescamine (Fluram) was from Fluka (Sigma-Aldrich, Copenhagen, Denmark). Leucine standard and the matrix $\alpha$-cyano-4-hydroxycinnamic acid were from Sigma-Aldrich. Column material (C18) for batch elution of peptides was from PerSeptive Biosystems (Framingham, MA). The peptide calibration standard, 1,000 to 4,000 Da (PepMix), used for calibration of the MALDI-time of flight (TOF) MS/MS and the MALDI AnchorChip target plate was from Bruker Daltonics GmbH (Bremen, Germany).

\section{Sample Preparation}

Immediately after the morning milking, 2 dairy cows were infused in 1 quarter each with $10 \mu \mathrm{g}$ of LTA from Staph. aureus that caused mastitis (Yang et al. 2008), diluted in $10 \mathrm{~mL}$ of saline $(9 \mathrm{~g} / \mathrm{L})$. One control quarter received only saline. Milk samples $(300 \mathrm{~mL})$ were collected from the gland to be infused and from the control gland before infusion $(t=0)$, and after 6,12 , 48 , and $144 \mathrm{~h}$; samples were obtained by hand milking during routine milking procedures. Somatic cell count measurements were performed with a DeLaval cell counter (Tumba, Sweden). Whole milk samples used for subsequent studies were frozen $\left(-18^{\circ} \mathrm{C}\right)$ until analysis. Before analysis, milk samples were thawed and skim milk was prepared by centrifugation $(3,000 \times g, 15 \mathrm{~min}$, $4^{\circ} \mathrm{C}$ ) with a Heraeus multifuge $3 \mathrm{~S}-\mathrm{R}$ (Kendro Laboratory, Albertslund, Denmark). After removal of the fat layer, the skim milk was centrifuged again to remove fat remnants. 


\section{Determination of Plasmin Activity}

Milk samples were mixed 3:1 with $0.4 M$ trisodium citrate (Richardson and Pearce, 1981) and centrifuged at $15,800 \times g$ for $30 \mathrm{~min}$ before assaying the supernatant for plasmin activity. Plasmin activity in milk was determined as described by Richardson and Pearce (1981) using the substrate $N$-succinyl-L-alanyl-L-phenylalanyl-L-lysyl-7-amido-4-methyl coumarin (Sigma Chemical Co., St. Louis, MO), from which plasmin produces 7-amido-4-methylcoumarin (AMC). Plasmin activity was expressed as nanomoles of 7-amido-4methylcoumarin released/min per milliliter of milk.

\section{Assessment of Proteolysis During Storage}

Milk samples were incubated at $37^{\circ} \mathrm{C}$ for $0,1,3$, or $7 \mathrm{~d}$, with sodium azide $(0.5 \mathrm{~g} / \mathrm{L})$ to prevent microbial growth. Milk samples were then mixed 1:1 with sample buffer and incubated at $40^{\circ} \mathrm{C}$ for $5 \mathrm{~min}$. Urea-PAGE of milk samples was then performed using a Protean II xi vertical slab gel unit (Bio-Rad Laboratories Ltd., Hemel Hempstead, UK) with a separating and stacking gel system according to the method of Andrews (1983). Gels were prerun at $280 \mathrm{~V}$ for $30 \mathrm{~min}$ before sample application, and samples were run at $300 \mathrm{~V}$. Gels were stained using $0.1 \%$ (wt/vol) Coomassie Brilliant Blue $\mathrm{R} 250$ in a 5:1:4 mixture of methanol, acetic acid, and deionized water and destained in a 7:5:88 mixture of methanol, acetic acid, and deionized water until the gels became clear. Gels were then scanned using a GS-800 calibrated densitometer (Bio-Rad Laboratories Ltd.).

\section{Two-Dimensional Electrophoresis}

Isoelectric focusing was carried out with a Protean IEF cell (Bio-Rad, Hercules, CA) according to the manufacturer's instructions. The milk protein samples $(40 \mu \mathrm{L})$ were mixed with a rehydration buffer $(8 \mathrm{M}$ urea, $2 \% 3$-[(3-cholamidopropyl)dimethylammonio]1-propanesulfonate, $50 \mathrm{mM}$ dithiothreitol, $0.2 \%$ BioLyte 3/10 ampholyte, and $0.001 \%$ bromophenol blue). Mixed samples $(125 \mu \mathrm{L})$ were loaded onto immobilized $\mathrm{pH}$ gradient strips ( $\mathrm{pH} 3-10,7 \mathrm{~cm}$; Bio-Rad), which were then passively rehydrated for $8 \mathrm{~h}$, followed by active rehydration overnight for $8 \mathrm{~h}$. The immobilized $\mathrm{pH}$ gradient strips were then focused at $20^{\circ} \mathrm{C}$ until 20,000 $\mathrm{kV}$ was reached. After focusing, the strips were immediately used for second-dimension SDS-PAGE. The SDS-PAGE was carried out under reducing conditions using 15\% acrylamide in a Criterion Dodeca cell unit (Bio-Rad). Prior to SDS-PAGE, the focused immobilized $\mathrm{pH}$ gradient strips were equilibrated with $50 \mathrm{mM}$ Tris $\mathrm{HCl}$ (pH 8.8), $6 \mathrm{M}$ urea, $30 \%$ glycerol, $2 \%$ SDS, and $130 \mathrm{~m} M$ dithiothreitol and alkylated in the same buffer containing $130 \mathrm{~m} M$ iodoacetamide instead of dithiothreitol. The gels were run at $200 \mathrm{~V}$ for $50 \mathrm{~min}$, stained using colloidal Coomassie blue (Chevalier et al., 2004), and images from stained gels were digitized at 300 dpi with a GS-800 calibrated densitometer (BioRad Laboratories Ltd.).

\section{Preparation of Peptide-Enriched Acid Whey Fractions and Fluorescamine Assay}

Acid whey fractions were prepared by acidification with 30 to $35 \mu \mathrm{L}$ of $10 \%$ acetic acid $/ \mathrm{mL}$ of skim milk sample to $\mathrm{pH}$ 4.6. An equal volume of $1 M$ sodium acetate was then added to maintain the $\mathrm{pH}$ at 4.6 and centrifugation was carried out at $1,500 \times g$ for $10 \mathrm{~min}$ at $5^{\circ} \mathrm{C}$ to separate the whey fraction from the $\mathrm{CN}$. The whey fraction $(500 \mu \mathrm{L})$ was further ultrafiltered under centrifugation, at $10,000 \times g$ for $45 \mathrm{~min}$ at $10^{\circ} \mathrm{C}$, in Micron YM-10 filter units (Millipore) with a molecular cut-off value of 10,000 Da. Aliquots of ultrafiltered acid whey samples were stored at $-18^{\circ} \mathrm{C}$ until further analysis. The levels of free amino terminals in the peptideenriched acid whey fractions were determined by the fluorescent probe, fluorescamine, using the method described by Larsen et al. (2004). The fluorescence values were expressed as millimolar leucine equivalents based on a standard curve of leucine (0.5 to $1.5 \mathrm{mM}$ ) dissolved in $1 \mathrm{~m} M \mathrm{HCl}$.

\section{Separation of Peptides by Capillary RP-HPLC}

An Agilent 1100 Series capillary HPLC system (Agilent Technologies 2000, Waldbronn, Germany), consisting of a capillary pump, autosampler, valve, microvacuum degasser, thermostatically controlled column compartment, variable wavelength detector, cooled microwell-plate autosampler/MALDI target spotter, and the Agilent Chemstation software was used. The whey filtrate $(0.5 \mu \mathrm{L})$ was injected onto a $\mathrm{C} 18$ reversedphase (RP)-HPLC column (Agilent Zorbax 300SB, 150 $\times 0.5 \mathrm{~mm}, 300 \AA, 5 \mu \mathrm{m})$ and eluted using a step-based gradient from $100 \%$ buffer A $(0.1 \%$ TFA in ultrapure water) to $55 \%$ buffer B (0.1\% TFA in $80 \%$ acetonitrile) for $15 \mathrm{~min}$, over $5 \mathrm{~min}$ to $60 \% \mathrm{~B}$, and to $100 \% \mathrm{~B}$ for 10 min. Column temperature was $20^{\circ} \mathrm{C}$ and the flow rate was $10 \mu \mathrm{L} / \mathrm{min}$. Detection was monitored at 210 and $280 \mathrm{~nm}$. The eluted peptides in each peak were spotted by peak according to absorbance at $210 \mathrm{~nm}$ directly onto the anchors of the MALDI target plate. A saturated solution $(0.4 \mu \mathrm{L})$ of the matrix $\alpha$-cyano-4hydroxycinnamic acid in 70\% acetonitrile, 0.1\% TFA, was added to all dried spots. 
Table 1. Somatic cell count (thousands of cells $/ \mathrm{mL}$ ) of milk samples from cow $\mathrm{A}$ and $\mathrm{B}^{1}$

\begin{tabular}{lcrcc}
\hline Time $(\mathrm{h})$ & $\begin{array}{c}\text { Cow A } \\
\text { control }\end{array}$ & $\begin{array}{c}\text { Cow A } \\
\text { infused }\end{array}$ & $\begin{array}{c}\text { Cow B } \\
\text { control }\end{array}$ & $\begin{array}{c}\text { Cow B } \\
\text { infused }\end{array}$ \\
\hline 0 & 11 & 62 & 135 & 32 \\
6 & 63 & 2,093 & 296 & 3,794 \\
12 & 26 & 467 & 106 & 2,780 \\
48 & 15 & 323 & 53 & 3,185 \\
144 & 8 & 42 & 70 & 114 \\
\hline
\end{tabular}

${ }^{1}$ Time indicates hours after infusion with lipoteichoic acid.

\section{Batch Elution of Peptides from Ultrafiltered Acid Whey Using Handmade RP Columns}

Handmade chromatographic columns were used as an alternative method for desalting and concentration of the peptides in the peptide-enriched acid whey preparations before mass spectrometric analysis according to the method of Gobom et al. (1999). The column was equilibrated in $0.1 \%$ TFA. Twenty microliters of the peptide-enriched acid whey fraction were loaded, the column was washed in $0.1 \%$ TFA, and the peptides were eluted in $\alpha$-cyano-4-hydroxycinnamic acid (20 $\mathrm{mg} / \mathrm{mL}$ ) in $50 \%$ acetonitrile directly onto the MALDI target plate in volumes of 0.5 to $1 \mu \mathrm{L}$.

\section{Identification of Peptides by MALDI-TOF MS/MS}

A peptide calibration standard $(0.2 \mu \mathrm{L})$ was manually spotted to a separate anchor of the MALDI target plate. The calibration standard contained 7 standard peptides ranging in molecular mass from $1,046.54$ to 3,147.47 Da. A Bruker Ultraflex MALDI-TOF tandem mass spectrometer (Bruker Daltonik GmbH, Bremen, Germany) was used in reflectron mode for mass analysis of separated peptides. The instrument was calibrated using the monoisotopic masses of the peptides in the calibration standard. The ion accelerating voltage was $25 \mathrm{kV}$, with a delay time of $40 \mathrm{~ns}$, the laser frequency was $50 \mathrm{~Hz}$, and 200 laser shots were accumulated for each spectrum. Peptides were measured as $[\mathrm{M}+\mathrm{H}]^{+}$. The ion accelerating voltage in MS/MS mode was 19 $\mathrm{kV}$. For MS/MS, dominant parent peaks in the MS spectrum were selected for further fragmentation in MS/MS mode followed by mass searches in the Swiss Prot database (Swiss Institute of Bioinformatics, Geneva, Switzerland) using the ion search program Mascot (Matrix Science, Boston, MA). Mascot settings included "none" for enzyme, and 1 missed cleavage was allowed. Error tolerance was $100 \mathrm{ppm}$ for parent mass and 0.5 $\mathrm{Da}$ for the fragment ion. In Mascot, the experimental mass value obtained from MS/MS is compared with calculated masses from a database. A scoring algorithm is used to identify the closest match and significant $(P$
$<0.05)$ peptide identifications were reported. A few of the peptides were manually elucidated from the fragments from the parent ion instead of using Mascot.

\section{RESULTS}

\section{SCC, Total Proteolysis, and Plasmin Activity After Infusion}

The SCC of milk from the control and infused quarters of cow A and B are shown in Table 1. Both cows showed a very large increase in SCC, from normal initial levels expected for healthy animals (within $6 \mathrm{~h}$ of infusion), to a greater extent in cow B than in cow A, with SCC in both cases slowly returning to near original levels thereafter (Table 1).

Overall levels of proteolysis in acid whey samples prepared from the milk samples during the time course of infusion were estimated by determination of the level of free amino terminals in the whey samples, which clearly increased after infusion with LTA; the highest level was observed in animal A milk $6 \mathrm{~h}$ after infusion (Table 2). In both animals, the levels increased from 0 to $6 \mathrm{~h}$ after infusion but, in milk from animal $\mathrm{A}$, the level decreased again from $6 \mathrm{~h}$ onward, whereas in animal B, essentially the same level was found $12 \mathrm{~h}$ after infusion.

Plasmin activity in milk samples likewise varied somewhat between the 2 animals. Activity in milk from the infused quarters reached its highest level $48 \mathrm{~h}$ after infusion for cow A, but $12 \mathrm{~h}$ after infusion for cow B, where a very high activity was observed (Figure 1), which was later than the peaks in SCC and free amino terminals.

\section{Electrophoretic Studies of Proteolysis}

The proteolysis patterns in milk samples from cows infused with LTA and incubated for up to $7 \mathrm{~d}$ at $37^{\circ} \mathrm{C}$ were first studied with urea-PAGE. The control (i.e., milk from the uninfused quarter) samples from cow A showed slow proteolysis, mainly of $\beta-\mathrm{CN}$ and to a lesser extent $\alpha_{\mathrm{S}_{1}} \mathrm{CN}$, for all samples during incubation for $7 \mathrm{~d}$ at $37^{\circ} \mathrm{C}$. However, electrophoretograms of the milk samples from the LTA-infused quarter of cow A showed a very significant increase in overall proteolysis

Table 2. Level of free amino terminals in milk from cow A and B infused glands, expressed as $\mathrm{m} M$ leucine equivalents (mean values of 5 replicates with SD)

\begin{tabular}{lcc}
$\begin{array}{l}\text { Time after } \\
\text { infusion }(\mathrm{h})\end{array}$ & Cow A & Cow B \\
\hline 0 & $2.53 \pm 0.059$ & $2.58 \pm 0.039$ \\
6 & $5.85 \pm 0.084$ & $3.59 \pm 0.083$ \\
12 & $3.66 \pm 0.072$ & $3.65 \pm 0.033$ \\
\hline
\end{tabular}




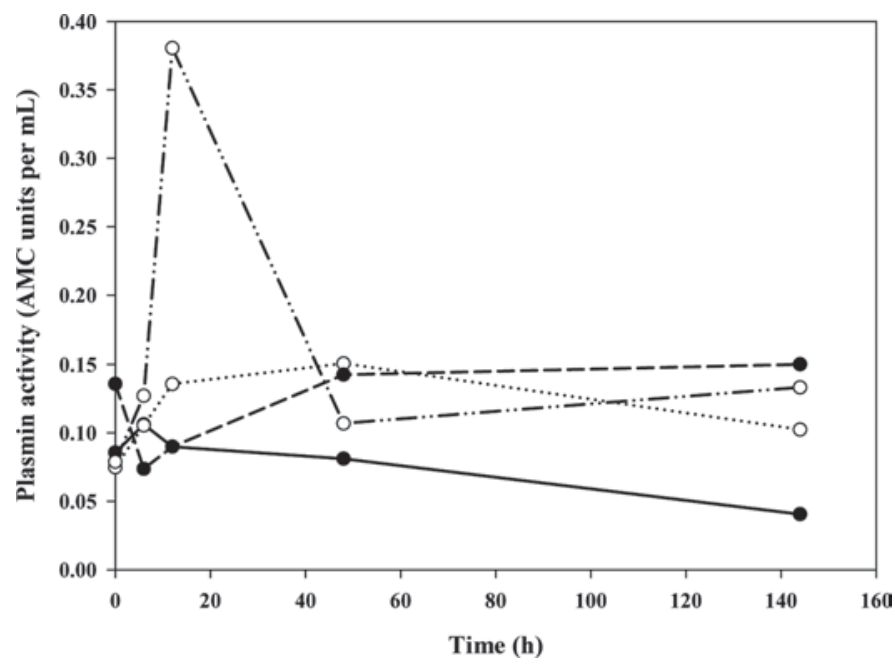

Figure 1. Plasmin activity of control quarters and infused quarters of cow A control (-—), cow A infused (..○..), cow B control (--•--), and cow B infused $(\cdot \cdot-\mathrm{O}-\cdot \cdot)$.

over incubation (Figure 2). Although the 0-h samples showed only a little breakdown of the CN over incubation, samples taken $6 \mathrm{~h}$ after infusion showed almost complete hydrolysis of $\beta$-and $\alpha_{S_{1}}$ CN within $1 \mathrm{~d}$ of incubation, with hydrolysis of $\beta$-CN being faster than that of $\alpha_{\mathrm{S} 1}-\mathrm{CN}$. Samples taken 12 and $48 \mathrm{~h}$ after infusion also showed rapid hydrolysis of $\mathrm{CN}$, but not as fast as that after $6 \mathrm{~h}$. After $144 \mathrm{~h}$, the proteolysis profile returned to almost normal (e.g., similar to the 0 -h sample). The urea-PAGE pattern for milk samples from control and LTA-infused quarters of cow B also showed a massive increase in hydrolysis of $\beta$ - and $\alpha_{\mathrm{S}_{1}} \mathrm{CN}$ in the sample taken $6 \mathrm{~h}$ after infusion, and a subsequent gradual return to a more normal level of hydrolysis (not shown).
The protein patterns in the control and infused quarter samples from cow A (not shown) and cow B (control quarter and quarter infused after $6 \mathrm{~h}$ ) were also analyzed by using 2 -dimensional gel electrophoresis. The resulting protein maps (Figure 3) compare milk samples from a control quarter (A) and a quarter into which LTA had been infused, at the height of the response (B). Immediately after infusion, the profile showed much intact $\alpha_{\mathrm{s} 1^{-}}$and $\beta-\mathrm{CN}$, but $6 \mathrm{~h}$ after infusion, the protein profile showed hydrolysis of $\alpha_{\mathrm{s} 1}$-and $\beta-\mathrm{CN}$, with the extent of breakdown being higher for $\beta-\mathrm{CN}$ than for $\alpha_{\mathrm{S} 1}-\mathrm{CN}$. In addition, higher molecular weight products appeared on the gel in the higher isoelectric point regions, as did lower molecular weight products.

\section{Identification of Peptides}

Peptides generated as a result of increased proteolysis after infusion were further characterized by peptidomic methods to identify possible proteases responsible for hydrolysis through the determination of cleavage sites. Initially, the peptides were analyzed by capillary RPHPLC of the peptide-enriched acid whey fractions from cow $\mathrm{A}$ and $\mathrm{B}$ taken 0,6 , and $12 \mathrm{~h}$ after infusion (Figure $4 \mathrm{a}-\mathrm{c})$. Consistent with the level of free amino terminals (Table 2), both the number and concentration of detected peptides (i.e., the area under the curve) increased from 0 to $6 \mathrm{~h}$ after infusion, whereas the number and area of peaks decreased again from 6 to $12 \mathrm{~h}$ after infusion in the samples from animal A. By contrast, in cow $\mathrm{B}$, the peptide profiles of the samples 6 and $12 \mathrm{~h}$ after infusion were almost identical (not shown), consistent with the results for free amino terminals (Table 2). The peptide profiles of the 6- and 12-h samples from animal

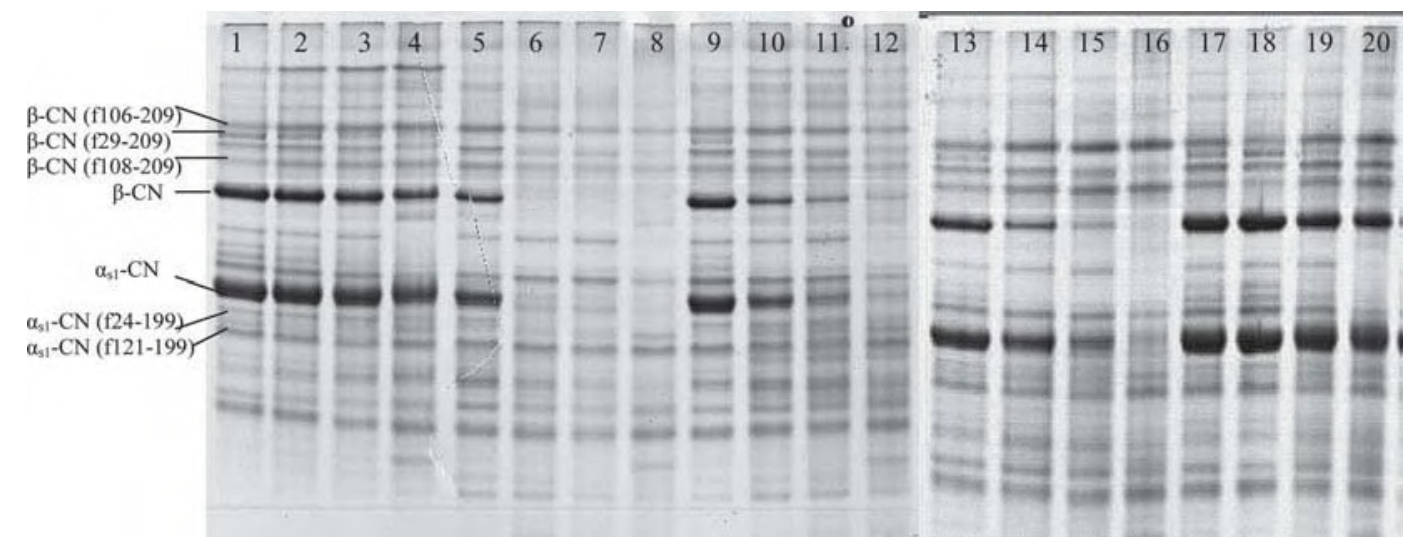

Figure 2. Urea-PAGE electrophoretograms of milk from the quarter samples of cow A infused with lipoteichoic acid and sampled after 0,6 , 12,48 , or $144 \mathrm{~h}$, and then incubated for $0,1,3$, or $7 \mathrm{~d}$ at $37^{\circ} \mathrm{C}$. Lane $1-4$ : 0 -h sample, incubated at $37^{\circ} \mathrm{C}$ for $0(1), 1(2), 3(3)$, or $7(4)$ d; lane 5-8: 6-h sample, incubated at $37^{\circ} \mathrm{C}$ for $0(5), 1$ (6), $3(7)$, or $7(8) \mathrm{d}$; lane $9-12$ : 12 -h sample, incubated at $37^{\circ} \mathrm{C}$ for $0(9), 1(10), 3(11)$, or $7(12)$ d; lane 13-16: 48-h sample, incubated at $37^{\circ} \mathrm{C}$ for 0 (13), 1 (14), 3 (15), or 7 (16) d; lane 17-20: 144-h sample, incubated at $37^{\circ} \mathrm{C}$ for 0 (17), 1 (18), 3 (19), or 7 (20) d. 

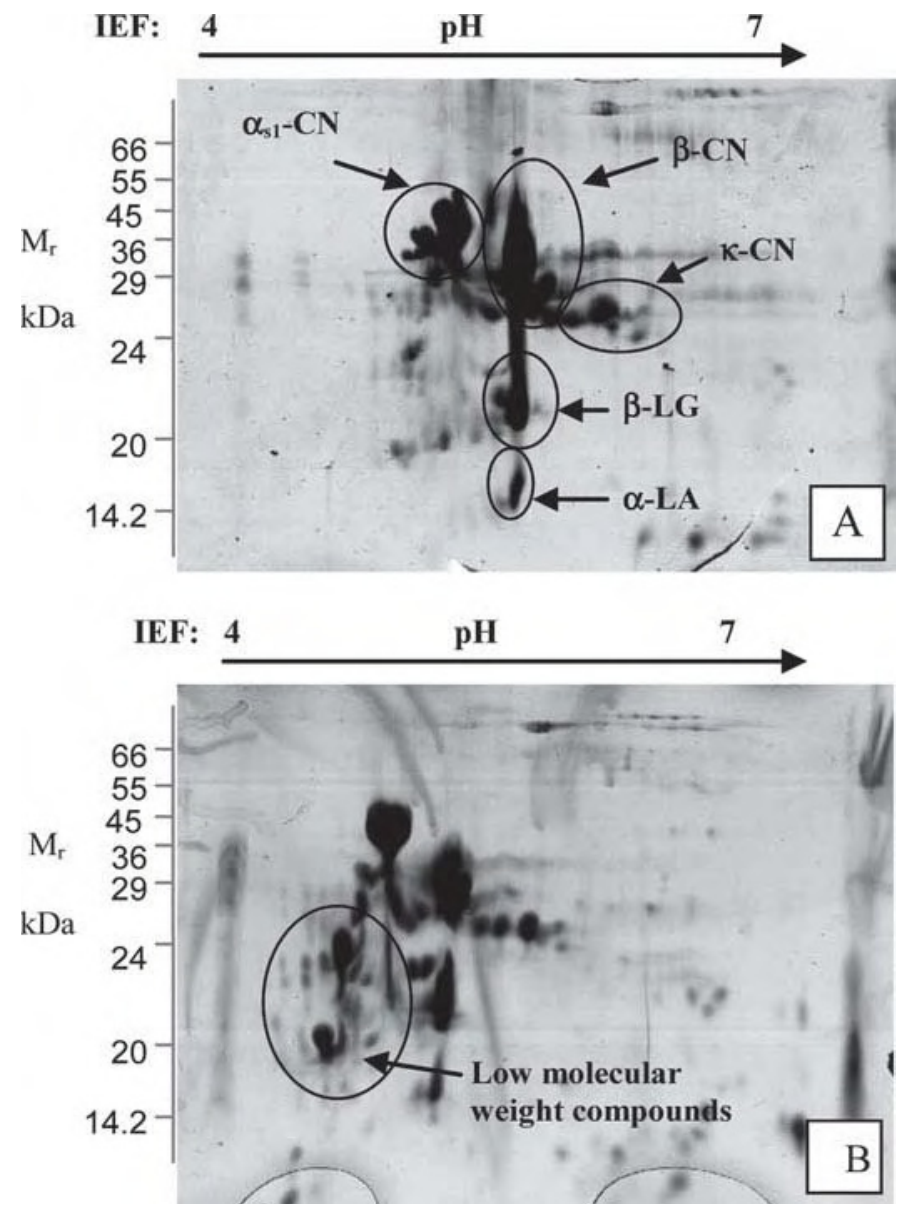

Figure 3. Two-dimensional gel electrophoretograms of milk from (A) the control quarter of cow $\mathrm{B} 0 \mathrm{~h}$ after infusion and (B) the infused quarter of cow B $6 \mathrm{~h}$ after infusion. The gels show molecular weights $\left(\mathrm{M}_{\mathrm{r}}\right)$ and isoelectric focusing at $\mathrm{pH} 4$ to 7 .
B were very similar to the $12 \mathrm{~h}$ sample from animal A (Figure 4).

For MS characterization and identification, the LCseparated peptides in the sample with the highest level of peptides (i.e., the $6 \mathrm{~h}$ sample from animal A) were spotted directly onto a MALDI target plate, based on the peak profile at $210 \mathrm{~nm}$. Peptides that could be identified by MS/MS eluted at between 22 and 30 min (Figure 4); MS identifications obtained by the LC-MALDI spotting procedure are shown in Table 3 . The peptides obtained from this spotting procedure are designated with the prefix S. A total of 9 peptides were identified in peaks $10,12,13,14,15$, and 23; peptides were not detected in other peaks in the chromatogram. Six of the identified peptides were derived from $\alpha_{\mathrm{S}_{1}} \mathrm{CN}(\mathrm{S} 1-3$, S7-9), and 3 were from $\beta-\mathrm{CN}$ (S4-6).

All peptides were identified by MS/MS analysis of the parent ions; an example of MS/MS analysis of 1 of the peptides (peptide S6; Table 3) is shown in Figure 5. The most dominant ion masses were $\mathrm{a}$, b, and y ions, according to the fragmentation nomenclature proposed by Roepstorff and Fohlmann (1984). Not all ions in the 3 series were detected, but the peptide sequence was assigned by the combined information from the 3 series. The measured mass of the parent peptide was $1,881.2$ Da. Taken together, the combined data demonstrated the detection of the peptide S6 with the sequence YQEPVLGPVRGPFPIIV, corresponding to a peptide from the C-terminal part of $\beta-\mathrm{CN}$ (193-209). The other peptides were similarly analyzed.

Because more peptides were expected to be present, especially in the unidentified peaks of the chromatograms, but could not be identified in the spotted ma-

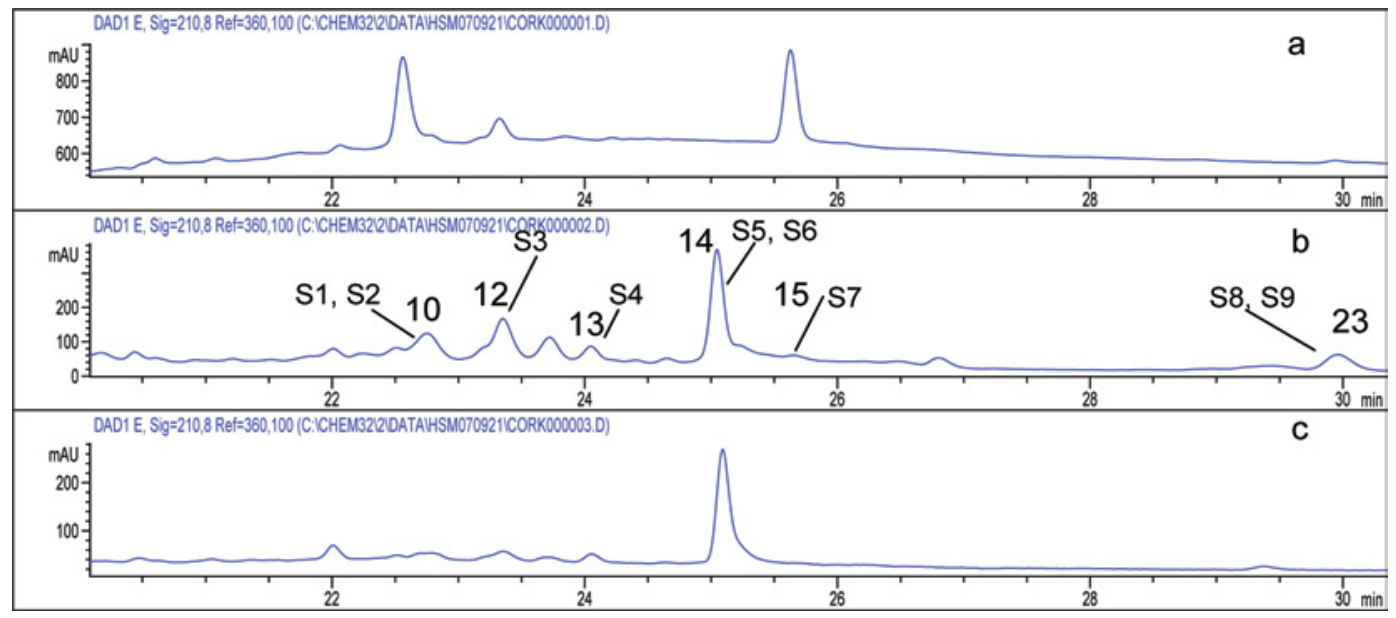

Figure 4. Capillary reverse-phased-HPLC profiles of peptides in peptide-enriched acid whey prepared from milk from animal A at 0, 6, and $12 \mathrm{~h}$ (panels a, b, and c, respectively) after infusion with LTA, respectively. Peaks were collected for tandem mass spectrometry analysis, and peptides (S1-7) were identified in peaks 10, 12, 13, 14, 15 and 23 (Table 3). Color version available in the online PDF. 
Table 3. Identity of peptides in peptide-enriched acid whey samples after liquid chromatography-matrix-assisted laser desorption ionization (LC MALDI) spotting (see Figure 4 for location of peptides) ${ }^{1}$

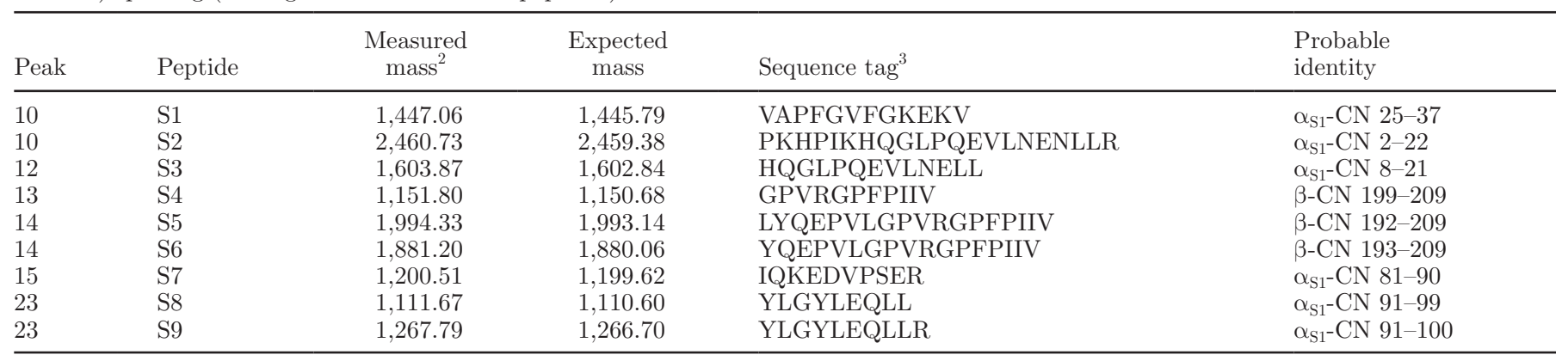

${ }^{1}$ The peptide masses and peptide sequences were determined by matrix-assisted laser desorption/ionization-time of flight tandem mass spectrometry analyses.

${ }^{2}$ The measured masses were detected as the mass $[\mathrm{M}+\mathrm{H}]^{+}$.

${ }^{3}$ The sequence tag used for tandem mass spectrometry identification.

terial from the LC (probably due to lower concentrations), an alternative approach to obtaining identifiable peptides was applied. By this method, the peptides in the 6-h sample from animal A were applied onto a handmade column containing RP material packed in a pipette tip, and concentrated 40 times by batch elution (i.e., $20 \mu \mathrm{L}$ of each whey sample was loaded onto this column instead of the $0.5 \mu \mathrm{L}$ loaded on the LC-system). The peptides eluted from the column were then directly and dropwise applied onto the MALDI target plate. An MS spectrum of the parent ions measured in one of the effluent drops on the AnchorChip plate (Bruker Daltonik GmbH, Bremen, Germany) is shown in Figure 6 , in addition to the resulting probable identities of the peptides as subsequently determined by MS/MS. A total of 14 peptides, including 5 from $\alpha_{\mathrm{S} 1}-\mathrm{CN}(\mathrm{A} 1-5)$ and 9 from $\beta$-CN (B1-9), were identified with this batchelution method. Three of the peptides were identified by both methods ( $\mathrm{S} 1=\mathrm{A} 6, \mathrm{~S} 2=\mathrm{A} 2$, and $\mathrm{S} 6=\mathrm{B} 8)$. Some of the peptides were derived from similar regions of the protein backbones, but showed minor differences in chain lengths. From $\alpha_{\mathrm{S}_{1}} \mathrm{CN}$, the $\alpha_{\mathrm{S}^{-}} \mathrm{CN}$ fragment 1-23 (A1) was identified, in addition to its processed variants, $\alpha_{\mathrm{S}_{1}} \mathrm{CN}$ 2-22 (A2) and 2-23 (A3). Furthermore, the resulting counterpart of $\alpha_{\mathrm{S}_{1}}$ - $\mathrm{CN}$ after the liberation of the $\alpha_{S 1}-\mathrm{CN}$ N-terminal fragment was represented by the peptide A4, in addition to a processed form, peptide A5. For $\beta-\mathrm{CN}$, all peptides identified (B1-9) comprised different peptides of varying chain length derived from the region between residue 163 and the C-terminus of the molecule, at position 209.

\section{DISCUSSION}

Both LTA from gram-positive Staph. aureus and LPS from gram-negative $E$. coli have been used in earlier infusion studies to elicit experimental mastitis (Moussaoui et al., 2002; Strandberg et al., 2005), but the effects on the milk proteolytic systems mainly have been studied in LPS infusion studies (Moussaoui et al., 2004; Haddadi et al., 2006). Staphylococcus aureus and E. coli account for the majority of clinical mastitis cases in cattle (Barkema et al., 1998), and it has been shown that not only infection with these live bacteria, but also infusion with LPS or LTA elicit different innate immune responses in bovine mammary cells (Bannerman et al., 2004; Strandberg et al., 2005) through differential expression of cytokines. The cytokine response to LTA was limited compared with that elicited by LPS, which suggested a reason as to why mastitis caused by gram-positive bacteria more often leads to chronic infection than that by gram-negative bacteria (Strandberg et al., 2005). The differential cytokine responses led to differences in the composition and maturation of somatic cells, and possibly affected the secretion of cellular enzymes into milk.

Mastitis induced by intramammary infusion with LTA from gram-positive Staph. aureus resulted in a significant increase in SCC in both cows studied, as was expected and is consistent with other studies of $E$. coli or Staph. aureus mastitis (Michelutti et al., 1999; Bannerman et al., 2004; Moussaoui et al., 2004; Haddadi et al., 2006). A high SCC is accompanied by an increase in proteolytic activity and subsequent negative effects on the yield and quality of dairy products such as cheese. The increased plasmin activity in the milk from infused glands is also consistent with previous results showing activation of the plasmin system during experimentally induced mastitis infections in cows by either Staph. aureus or E. coli (Grieve and Kitchen, 1985; Saeman et al., 1988; Heegaard et al., 1994; Moussaoui et al., 2002). It is interesting that the plasmin activity peaked later than did maximum SCC, which may suggest a separate mechanism for increasing activity or a time lag due to activation of the enzyme by cell-associated PA.

Increased proteolysis in milk from infused quarters was evident from multiple analytical measurements. 


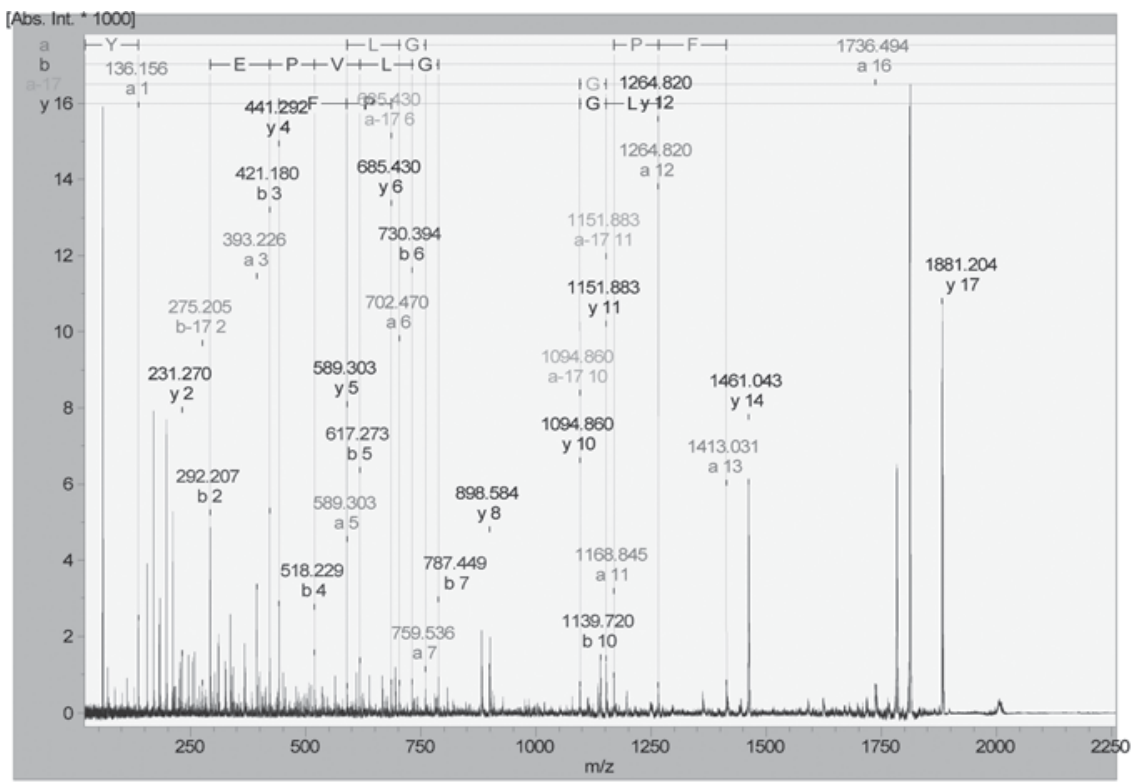

$\mathrm{M} / \mathrm{Z}$
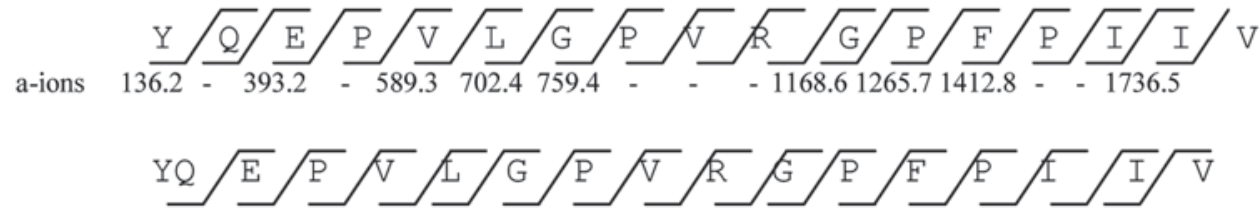

b-ions $\quad 292.2421 .2518 .2617 .3730 .4787 .4$ - $\quad$ - 1139.6 - $\quad$ - $\quad$ - $\quad$ -

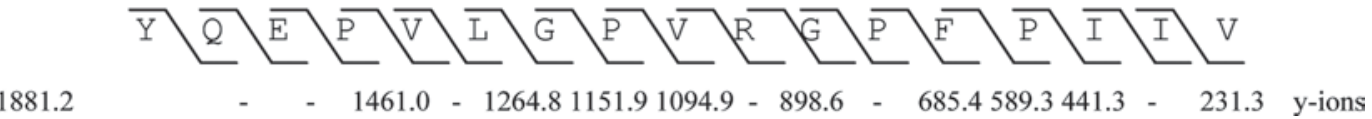

Figure 5. Matrix-assisted laser desorption/ionization-time of flight tandem mass spectrometry (MS/MS) of peptide S6 with parent mass of 1,881.2 Da. The a, b, and y ion series detected by MS/MS of the parent ion are indicated. The AA single-letter code is given for the sequence of the identified peptide S6, YQEPVLGPVRGPFPPIIV. The sequence was obtained by combination of the masses assigned to the a, $b$, and y-ion series.

Urea-PAGE electrophoretograms of the milk from the control quarter of cow A sampled after 0 and $6 \mathrm{~h}$ showed only slow hydrolysis of $\alpha_{\mathrm{s}}$ - and $\beta$-CN during incubation at $37^{\circ} \mathrm{C}$, which is consistent with previous reports for good quality milk; this indicates that hydrolysis of $\beta$-CN is due primarily to plasmin (Kelly and McSweeney, 2003; Schroeder et al., 2008). In contrast, electrophoretograms of the milk from the infected quarter sampled after $6 \mathrm{~h}$ and then incubated at $37^{\circ} \mathrm{C}$ showed complete hydrolysis of $\alpha_{S^{-}}$and $\beta$-CN, with $\beta$-CN being hydrolyzed faster. This initial phase of extensive proteolysis was in agreement with the increased plasmin activity. Greatly increased proteolysis after infusion with LTA was also apparent from measurements of levels of free amino terminals.
Other studies have also shown that CN undergoes extensive hydrolysis in milk from infected glands (Schaar, 1985; Le Roux et al., 1995; Leitner et al., 2006). In many previous studies of proteolysis during mastitis, infection was caused by live bacteria (e.g., Strep. uberis, Larsen et al., 2004; or E. coli, Moussaoui et al., 2004). In such cases, the bacteria themselves may have contributed to the proteolysis occurring (e.g., as observed for E. coli, Haddadi et al., 2006). However, in this study, the contribution of bacterial proteases to the observed proteolytic changes in mastitic milk may be excluded as the cows were infused with LTA only.

Barry and Donnelly (1981) reported that $90 \%$ of the proteinase activity in mastitic milk could be attributed to plasmin, but in contrast, de Rahm and Andrews 


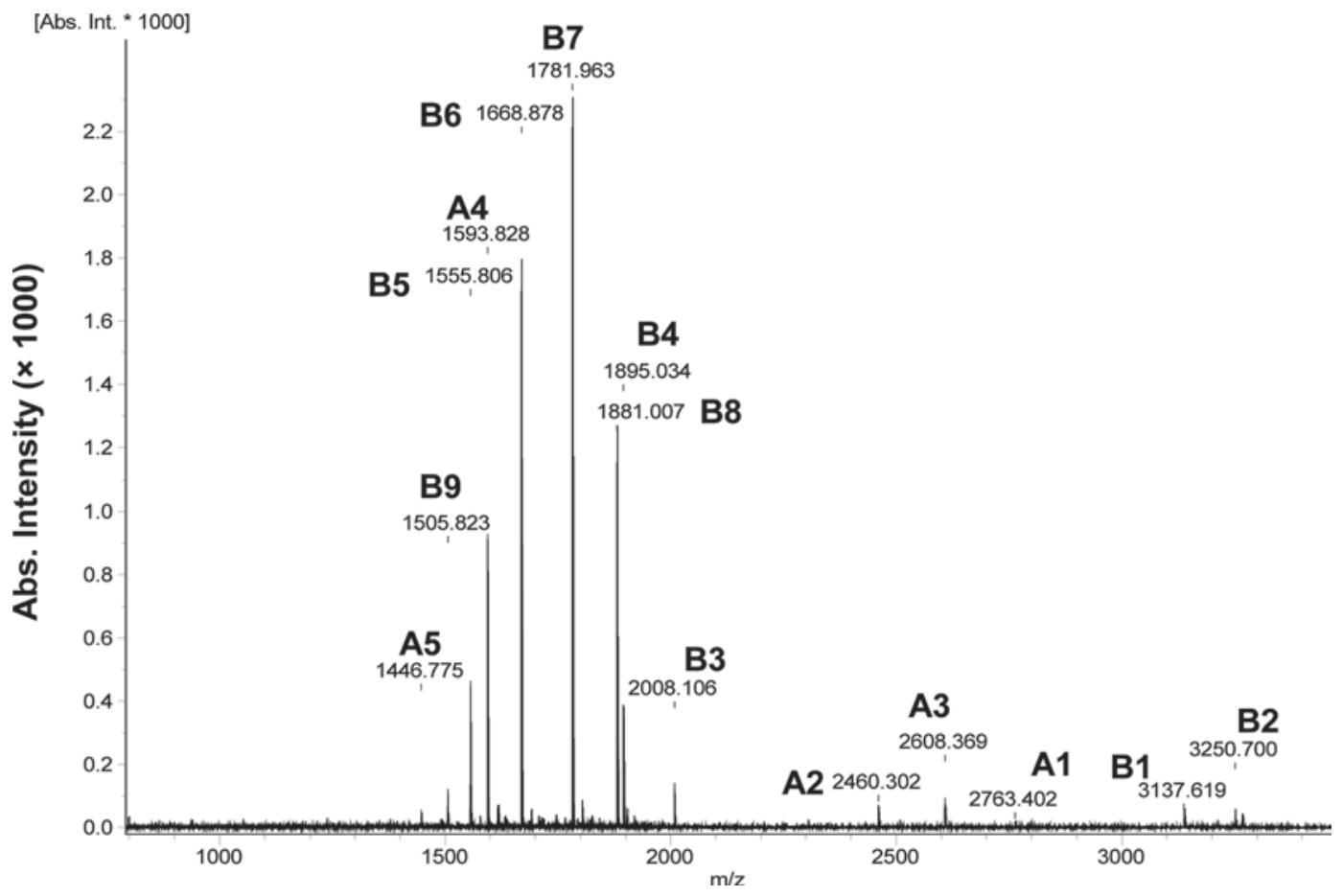

Figure 6. Matrix-assisted laser desorption/ionization-time of flight mass spectrometry (MS) profile of parent peptides obtained by batch elution of peptides. The measured masses of parent ions used for tandem MS analyses are indicated together with the identified peptides. The masses were determined as $[\mathrm{M}+\mathrm{H}]^{+}$. The peptides identified included: A1: RPKHPIKHQGLPQEVLNENLLRF; A2: PKHPIKHQGLPQEVLNENLLR; A3: PKHPIKHQGLPQEVLNENLLRF; A4: FVAPFPEVFGKV; A5: VAPFPEVFGKEKV; B1: LSLSQSKVLPVPQKAVPYPQRDMPIQAF; B2: LSLSQSKVLPVPQKAVPYPQRDMPIQAFL; B3: FLLYQEPVLGPVRGPFPII; B4: LLYQEPVLGPVRGPFPI, B5: YQEPVLGPVRGPFP; B6: YQEPVLGPVRGPFPI; B7: YQEPVLGPVRGPFPII; B8: YQEPVLGPVRGPFPIIV; and B9: QEPVLGPVRGPFPI.

(1982) reported that only one-third of the proteinase activity in such milk was due to plasmin. Similarly, Saeman et al. (1988), Le Roux et al. (1995), and Somers et al. (2003) showed that plasmin was not the only enzyme responsible for hydrolysis of $\mathrm{CN}$ in milk from cows with mastitis and concluded that proteinases from somatic cells and blood may also play a significant role in the CN hydrolysis of such milk. In LPS-induced mastitis, it has been shown that neutral proteinase activity was associated with immature PMN, the major somatic cell type in early inflammation (Saad and Östensson, 1990), whereas acidic proteinase activities, which could include cathepsins, were associated with mature PMN (Moussaoui et al., 2002). Some of the proteolysis products were subsequently identified in such studies, and comprised fragments of all $4 \mathrm{CN}$ produced by somatic cell proteases (Moussaoui et al., 2003). Enzyme activities associated with the PMN were later measured as elastase, collagenase, and cathepsins (Haddadi et al., 2006).

Proteases potentially responsible for the cleavages giving rise to these peptides are suggested in Table 4, based on earlier reports of enzyme specificities for CN substrates in model studies. Peptide S1 $\left(\alpha_{S_{1}}-\mathrm{CN} 25-37\right)$ could be the result of cathepsin B, D, or elastase activity, as in the case of cathepsin B or D combined with subsequent aminopeptidase trimming. Of the $\alpha_{S 1}$ CN peptides, 2 were differentiated only by 1 residue (S8 and S9); it is possible that peptide $\mathrm{S} 8$ is the result of carboxy-terminal trimming of the C-terminal arginine of S9, originally generated by plasmin. The peptides identified from $\beta$-CN comprised 3 related peptides (S4, $\mathrm{S} 5$, and S6), all derived from the C-terminal part of $\beta-C N$. Cathepsin D has been shown (Hurley et al., 2000) to be able to cleave the $\mathrm{Leu}_{191}-\mathrm{Leu}_{192}$ and the $\mathrm{Leu}_{192}-\mathrm{Tyr}_{193}$ bonds of this protein, giving rise to peptides S5 and S6, respectively (Table 4).

In Table 5, the enzymes likely responsible for the cleavages generating the peptides identified by batch elution are presented, based on their known preferences for cleavages in the $\mathrm{CN}$ as observed in model studies. All peptides had at least 1 cleavage site (N- or $\mathrm{C}$-terminal) that could be assigned to a potential responsible bovine protease, including cathepsins and elastase. Several peptides appeared in different related versions and, as for the RP-HPLC-separated peptides (Table 4), strongly indicated the occurrence of peptide trimming by aminopeptidase or carboxypeptidase activities. This 
Table 4. Suggested enzymes potentially responsible for the generation of the peptides S1-9, based on earlier reports ${ }^{1}$

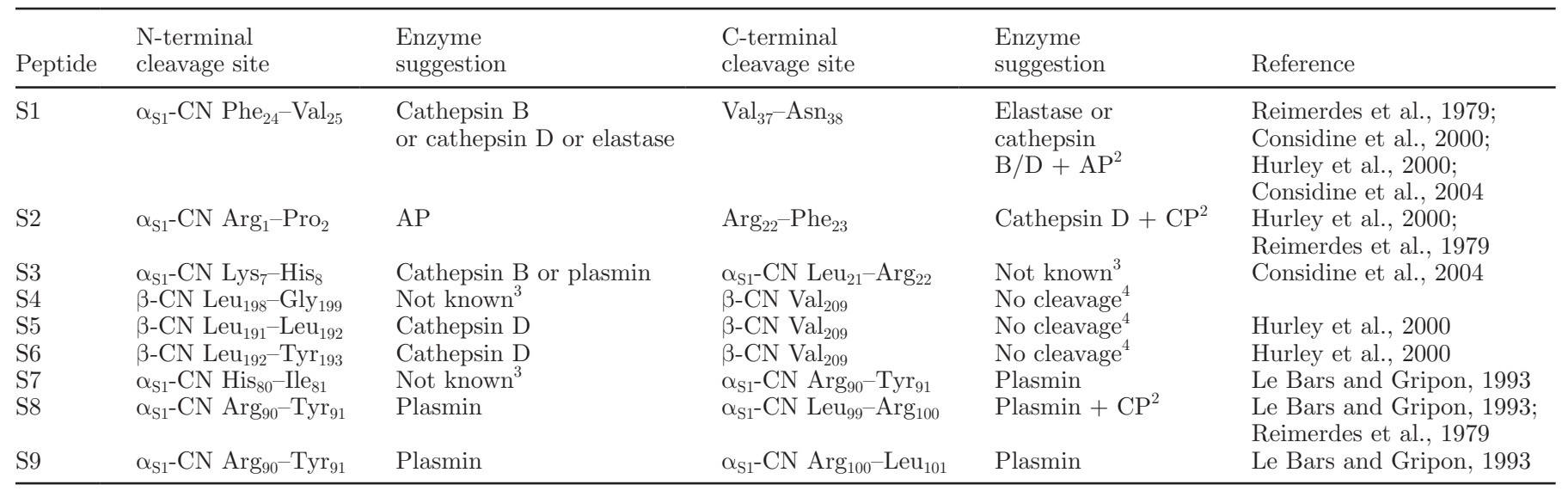

${ }^{1} \mathrm{AP}=$ aminopeptidase; $\mathrm{CP}=$ carboxypeptidase. More information on peptides $\mathrm{S} 1-9$ is available in Table 3.

${ }^{2} \mathrm{An} \mathrm{AP}$ or a $\mathrm{CP}$, eventually in combination with other protease(s), may be responsible for the cleavage.

${ }^{3}$ Not known indicates that a possible responsible protease for generation of this cleavage site could not be suggested.

${ }^{4}$ No cleavage indicates that the residue is located at the C-terminal position of the protein from which it was derived and therefore not the result of a proteolytic cleavage at that position.

was observed, for example, for the $\alpha_{\mathrm{S} 1}$ I CN fragment (A1), which also appeared in the processed forms A2 and A3. Various forms of the C-terminal fragment of $\beta-\mathrm{CN}$ also were identified, and indicated trimming, especially involving carboxy peptidase activity. In some instances, the assigned peptide appeared to be the result of combined actions of endo- and exoproteinase activities, as suggested for peptides B1, B2, and B9.

Taken together, the proteases suggested as potentially responsible for proteolysis in the present study included plasmin, cathepsin B, cathepsin D, neutrophil elastase, and one possible instance of cathepsin $\mathrm{G}$, in addition to presumed AA carboxypeptidase activities. All of these enzyme activities were suggested based on the milk sample analyzed $6 \mathrm{~h}$ after infusion, and thus indicate that both the plasmin/plasminogen system and somatic cell proteases seem to be involved in the breakdown of protein observed in early inflammation after infusion of LTA.

Several cleavage sites appeared to be the result of the action of either amino- or carboxy-peptidases, eventually in combination with other enzymes. The many indications of amino- or carboxy peptidase activities in the analyzed samples are surprising. The presence of aminopeptidase activity in milk serum has been previously reported (Reimerdes et al., 1979), but has not been confirmed by later studies. However, a potential candidate for such aminopeptidase activity could be cathepsin $\mathrm{H}$, which, apart from its endoproteinase activity, is an amino peptidase (Barrett and Kirschke, 1981). Cathepsin H is one among several lysosomal cysteine proteases with exopeptidase activity as well, but the presence of cathepsin $\mathrm{H}$ in milk has not been previously demonstrated.

Of the many potential cathepsin D cleavage sites in the CN (McSweeney et al., 1995; Larsen et al., 1996), only a small number were observed in the present study, including cleavage of the $\mathrm{Phe}_{23}-\mathrm{Phe}_{24}$ bond of $\alpha_{\mathrm{S} 1}-\mathrm{CN}$, resulting in the production of the $\alpha_{\mathrm{S} 1}-\mathrm{I} \mathrm{CN}$ fragment, which is well known to be generated during cheese ripening. That more cathepsin D cleavage sites were not identified probably reflects large differences in the susceptibility of pure individual caseins compared with caseins in milk systems. This may be due to both differences in $\mathrm{pH}$ and ionic strength of model systems compared with milk, but also to the fact that the caseins in milk are organized in micelles, which may protect in some degree toward hydrolysis. Possible cleavage sites for cathepsin B also were identified, but none of these was assigned to only this protease. Cathepsin B is a cysteine protease that requires a reducing milieu for activity, and this fact may limit its activity in milk. Apart from its endoproteinase activity, cathepsin B also acts as a carboxydipeptidase (i.e., it can cleave dipeptides from the C-terminus of some substrates; Barrett et al., 1988), and it has been reported that the endoproteinase activity of cathepsin B is relatively low compared with its carboxydipeptidase activity (Barrett and Kirschke, 1981).

Nine peptides were identified by the LC-MALDI spotting method. The level of some of the further peptides detected at $210 \mathrm{~nm}$ was apparently too low for MS identification by the procedure used, and therefore all of the peptide material in 1 of the samples was 
Table 5. Suggested enzymes potentially responsible for the generation of the identified peptides

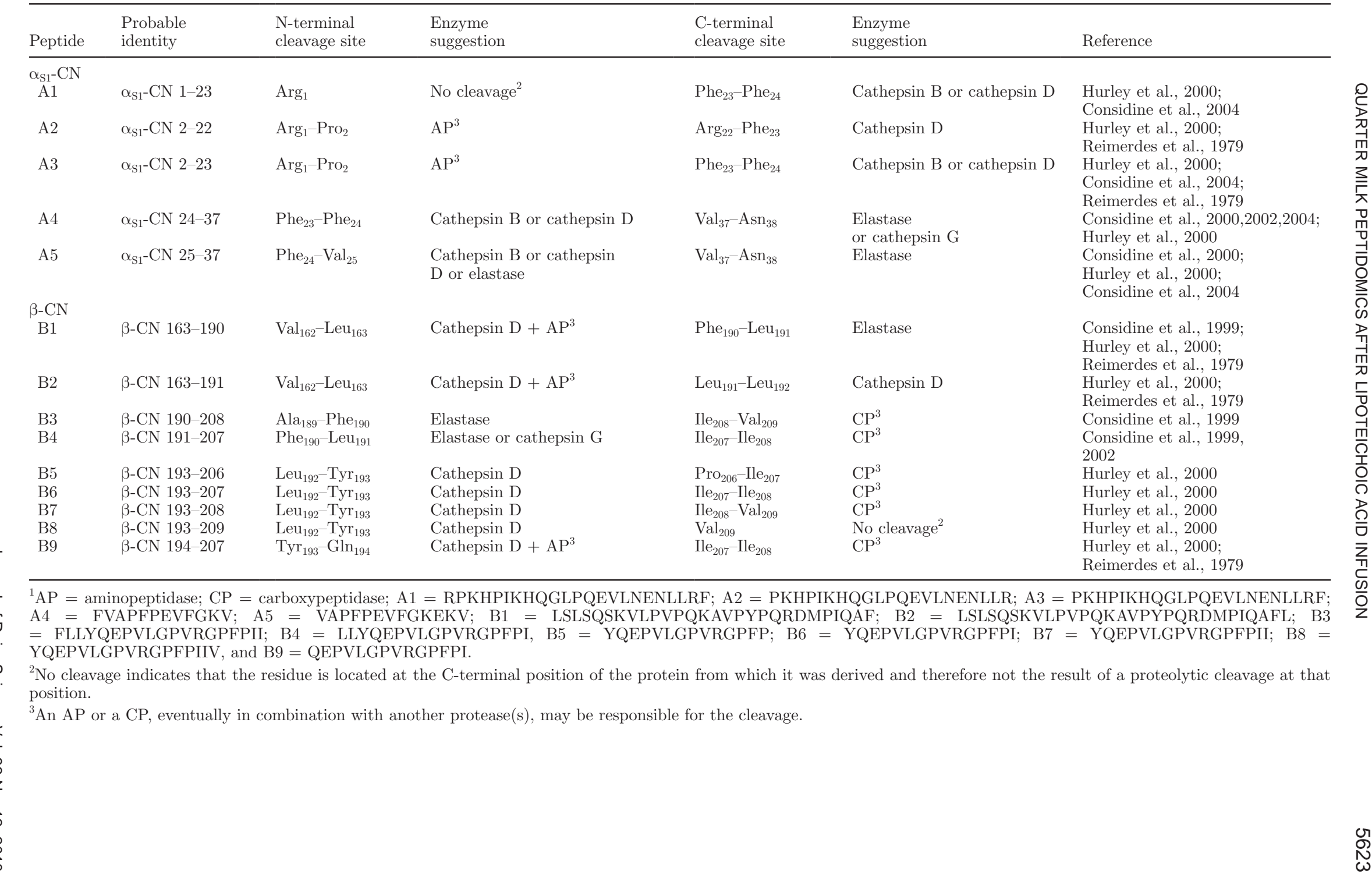


concentrated by batch elution from the $\mathrm{C} 18$ column material, which resulted in identification of 14 peptides. It is possible that even more peptides were present, but the identification of these would require a separate study and, for example, the use of complementary MS methods to improve detection and reliability (Stoop et al., 2008). The peptides identified included peptides from $\alpha_{\mathrm{S}^{-}}$and $\beta$-CN; no peptides were identified from $\alpha_{\mathrm{S} 2}$-CN. In an earlier study of mastitic milk, which was obtained after infection with the mastitis pathogen Strep. uberis, peptides from $\alpha_{\mathrm{S1}^{-}}, \alpha_{\mathrm{S}_{2}}$ and $\beta-\mathrm{CN}$ were identified (Wedholm et al., 2008). In the study of Moussaoui et al. (2003), peptides from all 4 CN were identified, but in this study a different approach was used involving N-terminal sequencing of protein bands from SDS-PAGE, thereby favoring larger fragments that could be retained in the gel. All peptides identified as originating from $\alpha_{S_{1}}-\mathrm{CN}$ were derived from the N-terminal part of that molecule, whereas all $\beta-\mathrm{CN}$ peptides were cleaved from the C-terminal part of the molecule, except for 3 peptides (S7-9) from $\alpha_{\mathrm{S}_{1}} \mathrm{CN}$, which were cleaved from the middle part. These peptides were all derived from the nonphosphorylated regions in the $\mathrm{CN}$, and therefore no phosphorylated peptides were identified. This is probably because of difficulties in detecting the phosphopeptides by the MS method applied; this aspect could be further studied by applying modified methods designed for detection of phosphorylated peptides (Stensballe and Jensen, 2004).

In relation to the peptide profile identified earlier in mastitic milk using LC-MALDI spotting (Wedholm et al., 2008), the peptide S4 identified in this study is identical to the peptide P8 identified earlier, and corresponds to $\beta-C N 199-209$, whereas peptide $\mathrm{S} 7\left(\alpha_{\mathrm{S} 1}-\mathrm{CN}\right.$ $81-90)$ from this study is almost identical to $\mathrm{P} 2\left(\alpha_{\mathrm{S} 1}-\mathrm{CN}\right.$ 80-92) identified in the earlier study. This shows that some of the cleavages and peptides occurring are the same in the 2 studies, but also that many cleavages and peptides are specific to different conditions of mastitis and elevated SCC.

Among the peptides identified, several had potential bioactive properties. These included $\alpha_{\mathrm{S} 1}-\mathrm{CN}$ 91-99 and 91-100, with opoid properties, and $\alpha_{\mathrm{S} 1}$-CN 1-23 (Isracidin) and $\beta-C N$ 193-209, with immune-modulating and antimicrobial activities (Silva and Malcata, 2005). This indicates that some of the endogenous enzymes in milk are capable of contributing to the generation of bioactive peptides in some milk types, and raises the possibility of bovine somatic cell enzyme involvement in the generation of antimicrobial peptides as a means to fight bacterial infection.

It is possible that further peptidomic studies of samples obtained from different cows or at other time points would identify additional peptides and suggest other enzymes to be involved. Further indications of actual enzyme activities could be obtained by characterization of specific enzyme activities, and this is currently being carried out, together with further characterization of larger CN hydrolysis products through the use of gel electrophoresis proteomic-based methods.

\section{ACKNOWLEDGMENTS}

The authors gratefully acknowledge the technical assistance of Stina G. Handberg (Department of Food Science, Aarhus University, Denmark). Part of this work was presented at the ADSA/ASAS conference in Montreal, QB, Canada, July 2009.

\section{REFERENCES}

Ali, A. E., A. T. Andrews, and G. C. Cheeseman. 1980. Influence of storage of milk on casein distribution between the micellar and soluble phases and its relationship to cheese-making parameters. J. Dairy Res. 47:371-382.

Andrews, A. T. 1983. Breakdown of caseins by proteinases in bovine milks with high somatic cell counts arising from mastitis or infusion with bacterial endotoxin. J. Dairy Res. 50:57-66.

Andrews, A. T., and E. Alichanidis. 1983. Proteolysis of caseins and the proteose-peptone fraction of milk. J. Dairy Res. 50:275-290.

Bannerman, D. D., M. J. Paape, J. W. Lee, X. Zhao, J. C. Hope, and P. Rainard. 2004. Escherichia coli and Staphylococcus aureus elicit differential innate immune responses following intramammary infection. Clin. Diagn. Lab. Immunol. 11:463-472.

Barkema, H. W., Y. H. Schukken, T. J. Lam, M. L. Beiboer, H. Wilmink, G. Benedictus, and A. Brand. 1998. Incidence of clinical mastitis in dairy herds grouped in three categories by bulk somatic cell count. J. Dairy Sci. 81:411-419.

Barrett, A. J., D. J. Buttle, and R. W. Mason. 1988. Lysosomal cysteine proteinases. Pages 256-260 in ISI Atlas of Science: Biochemistry, Cambridge University Press, Cambridge, UK.

Barrett, A. J., and H. Kirschke. 1981. Cathepsin B, cathepsin H, and cathepsin L. Methods Enzymol. 80(Part C):535-561.

Barry, J. G., and W. J. Donnelly. 1981. Casein compositional studies: II. The effect of secretory disturbance on casein composition in freshly drawn and aged bovine milks. J. Dairy Res. 48:437-446.

Bradley, A. J. 2002. Bovine mastitis: An evolving disease. Vet. J. 163:1-13.

Chevalier, F., V. Rofidal, P. Vanova, A. Bergoin, and M. Rossignol. 2004. Proteomic capacity of recent fluorescent dyes for protein staining. Phytochemistry 65:1499-1506.

Considine, T., S. Geary, A. L. Kelly, and P. L. H. McSweeney. 2002. Proteolytic specificity of cathepsin $\mathrm{G}$ on bovine $\alpha_{\mathrm{S1}^{-}}$and $\beta$-caseins. Food Chem. 76:59-67.

Considine, T., A. Healy, A. L. Kelly, and P. L. H. McSweeney. 1999. Proteolytic specificity of elastase on bovine $\beta$-casein. Food Chem. 66:463-470.

Considine, T., A. Healy, A. L. Kelly, and P. L. H. McSweeney. 2000. Proteolytic specificity of elastase on bovine $\alpha_{\mathrm{S}_{1}}$-casein. Food Chem. 69:19-26.

Considine, T., A. Healy, A. L. Kelly, and P. L. H. McSweeney. 2004. Hydrolysis of bovine caseins by cathepsin B, a cysteine proteinase indigenous to milk. Int. Dairy J. 14:117-124.

de Rahm, O., and A. T. Andrews. 1982. Qualitative and quantitative determination of proteolysis in mastitis milk. J. Dairy Res. 49:587-596.

Everson, T. C. 1984. Concerns and problems of processing and manufacturing in super plants. J. Dairy Sci. 67:2095-2099. 
Fox, P. F., and A. L. Kelly. 2006. Indigenous enzymes in milk: Overview and historical aspects-Part 1. Int. Dairy J. 16:500-516.

Gobom, J., E. Nordhoff, E. Mirgorodskaya, R. Ekman, and P. Roepstorff. 1999. Sample purification and preparation technique based on nano-scale reversed phase columns for the sensitive analysis of complex peptide mixtures by matrix-assisted laser desorption/ionization mass spectrometry. J. Mass Spectrom. 34:105-116.

Grieve, P. A., and B. J. Kitchen. 1985. Proteolysis in milk: The significance of proteinases originating from milk leukocytes and a comparison of the action of leukocyte, bacterial and natural milk proteinases on casein. J. Dairy Res. 52:101-112.

Haddadi, K., C. Prin-Mathieu, F. Moussaoui, G. C. Faure, F. Vangroenweghe, C. Burvenich, and Y. Le Roux. 2006. Polymorphonuclear neutrophils and Escherichia coli proteases involved in proteolysis of casein during experimental E. coli mastitis. Int. Dairy J. 16:639-647.

Heegaard, C. W., T. Christensen, M. D. Rasmussen, C. Benfeldt, N. E. Jensen, K. Sejrsen, T. E. Petersen, and P. A. Andreasen. 1994. Plasminogen activators in bovine milk during mastitis, an inflammatory disease. Fibrinolysis 8:22-30.

Heringstad, B., G. Klemetsdal, and J. Ruane. 2000. Selection for mastitis resistance in dairy cattle: A review with focus on the situation in the Nordic countries. Livest. Prod. Sci. 64:95-106.

Hurley, M. J., L. B. Larsen, A. L. Kelly, and P. L. H. McSweeney. 2000. Cathepsin D activity in quarg. Int. Dairy J. 10:453-458.

Jackson, K. W., N. Esmon, and J. Tang. 1981. Streptokinase and staphylokinase. Methods Enzymol. 80:387-394.

Kelly, A. L., and P. L. H. McSweeney. 2003. Indigenous proteolytic enzymes in milk. Pages 495-544 in Advanced Dairy Chemistry I (Proteins). 3rd ed. P. F. Fox and P. L. H. McSweeney, ed. Kluwer Academic-Plenum Publishers, New York, NY.

Kelly, A. L., F. O'Flaherty, and P. F. Fox. 2006. Indigenous proteolytic enzymes in milk: A brief overview of the present stage of knowledge. Int. Dairy J. 16:563-572.

Kirschke, H., and A. J. Barrett. 1987. Chemisty of lysosomal proteainases. Pages 193-238 in Lysosomes: Their Role in Protein Breakdown. H. Glaumann and F. J. Ballard, ed. Academic Press, New York, NY.

Larsen, L. B., C. Benfeldt, L. K. Rasmussen, and T. E. Petersen. 1996. Bovine milk procathepsin D and cathepsin D: Coagulation and milk protein degradation. J. Dairy Res. 63:119-130.

Larsen, L. B., P. L. H. McSweeney, M. G. Hayes, J. B. Andersen, K. L. Ingvartsen, and A. L. Kelly. 2006. Variation in activity and heterogeneity of bovine milk proteases with stage of lactation and somatic cell count. Int. Dairy J. 16:1-8.

Larsen, L. B., M. D. Rasmussen, M. Bjerring, and J. H. Nielsen. 2004. Proteases and protein degradation in milk from cows infected with Streptococcus uberis. Int. Dairy J. 14:899-907.

Larson, N. K., B. Ismail, S. S. Nielsen, and K. D. Hayes. 2006. Activity of Bacillus polymyxa protease on components of the plasmin system in milk. Int. Dairy J. 16:586-592.

Le Bars, D., and J.-C. Gripon. 1993. Hydrolysis of $\alpha_{\mathrm{S}_{1}}$-casein by bovine plasmin. Lait 73:337-344.

Le Roux, Y., O. Colin, and F. Laurent. 1995. Proteolysis in samples of quarters milk with varying somatic cell counts. 1. Comparison of some indicators of endogenous proteolysis in milk. J. Dairy Sci. 78:1289-1297.

Le Roux, Y., O. Colin, and F. Moussaoui. 2003. Polymorphonuclear proteolytic activity and milk composition change. Vet. Res. 34:629-645.

Leigh, J. A. 1994. Purification of a plasminogen activator from Streptococcus uberis. FEMS Microbiol. Lett. 118:153-158.

Leitner, G., O. Krifucks, U. Merin, Y. Lavi, and N. Silanikove. 2006. Interactions between bacteria type, proteolysis of casein and physico-chemical properties of bovine milk. Int. Dairy J. 16:648-654.

McSweeney, P. L. H., P. F. Fox, and N. F. Olson. 1995. Proteolysis of bovine caseins by cathepsin D: Preliminary observations and comparison with chymosin. Int. Dairy J. 5:321-336.
Michelutti, I., Y. Le Roux, P. Rainard, B. Poutrel, and F. Laurent. 1999. Sequential changes in milk protein composition after experimental Escherichia coli mastitis. Lait 79:535-549.

Moussaoui, F., F. Laurent, J. M. Girardet, G. Humbert, J. L. Gaillard, and Y. Le Roux. 2003. Characterization and proteolytic origins of specific peptides appearing during lipopolysaccharide experimental mastitis. J. Dairy Sci. 86:1163-1170.

Moussaoui, F., I. Michelutti, Y. Le Roux, and F. Laurent. 2002. Mechanisms involved in milk endogeneous proteolysis induced by a lipopolysaccharide experimental mastitis 2002. J. Dairy Sci. $85: 2562-2570$

Moussaoui, F., F. Vangroenweghe, K. Haddadi, Y. Le Roux, F. Laurent, L. Duchateau, and C. Burvenich. 2004. Proteolyis in milk during experimental Escherichia coli mastitis. J. Dairy Sci. 87:2923-2931.

Politis, I., E. Lachance, E. Block, and J. D. Turner. 1989a. Plasmin and plasminogen in bovine milk: A relationship with involution. J. Dairy Sci. 72:900-906.

Politis, I., K. F. Ng Kwai Hang, and R. N. Giroux. 1989b. Environmental factors affecting plasmin activity in milk. J. Dairy Sci. $72: 1713-1718$.

Pugin, J. 1994. Bacteremia, sepsis and shock. Intensive Care Med. 20:92-93.

Reimerdes, E. H., F. Petersen, and G. Kielwein. 1979. Milchproteinasen 9. Proteinasenaspektren von Caseinmicellen, Milchserum, Rinderblutserum und Pseudomonoas flourescens. Milchwissenschaft $34: 548-551$.

Richardson, B. C., and K. N. Pearce. 1981. The determination of plasmin in dairy products. N.Z. J. Dairy Sci. Technol. 16:209-220.

Roepstorff, P., and J. Fohlmann. 1984. Proposal for a common nomenclature for sequence ions in mass spectra of peptides. Biomed. Mass Spectrom. 11:601.

Saad, A. M., and K. Östensson. 1990. Flow cytometric studies on the of leucocyte populations in blood and milk during endotoxininduced mastitis in cows. Am. J. Vet. Res. 51:1603-1607.

Saeman, A. I., R. J. Verdi, D. M. Galton, and D. M. Barbano. 1988. Effect of mastitis on proteolytic activity in bovine milk. J. Dairy Sci. 71:505-512.

Schaar, J. 1985. Plasmin activity and proteose-peptone content of individual milks. J. Dairy Res. 52:369-378.

Schroeder, D. L., S. S. Nielsen, and K. D. Hayes. 2008. The effect of raw milk storage temperature on plasmin activity and plasminogen activation in pasteurized milk. Int. Dairy J. 18:114-119.

Silva, S. V., and F. X. Malcata. 2005. Caseins as source of bioactive peptides. Int. Dairy J. 15:1-15.

Sládek, Z., D. Rysánek, and M. Faldyna. 2002. Activation of phagocytes during initiation and resolution of mammary gland injury induced by lip polysaccharide in heifers. Vet. Res. 33:191-204.

Sohn, E. J., M. J. Paape, E. E. Connor, D. D. Bannerman, R. H. Fetterer, and P. R. Peters. 2007. Bacterial lipopolysaccharide stimulates bovine Europhile production of TNF-alpha, Il-1 beta, IL-12 and IFN-gamma. Vet. Res. 38:809-818.

Somers, J. M., B. O'Brien, W. Meaney, and A. L. Kelly. 2003. Heterogeneity of proteolytic enzyme activities in milk samples of different somatic cell count. J. Dairy Res. 70:45-50.

Sordillo, L. M., K. Shafer-Weaver, and D. DeRosa. 1997. Immunobiology of the mammary gland. J. Dairy Sci. 80:1851-1865.

Stensballe, A., and O. N. Jensen. 2004. Phosphoric acid enhances the performance of $\mathrm{Fe}(\mathrm{III})$ affinity chromatography and matrixassisted laser desorption/ionization tandem mass spectrometry for recovery, detection and sequencing of phosphopeptides. Rapid Commun. Mass Spectrom. 18:1721-1730.

Stoop, M. P., R. J. Lamers, P. C. Burgers, P. A. E. S. Smitt, R. Q. Hintzen, and T. M. Luider. 2008. The rate of false positive sequence matches of peptides profiled by MALDI MS and identified by MS/MS. J. Proteome Res. 7:4841-4847.

Strandberg, Y., C. Gray, T. Vuocolo, L. Donaldson, M. Broadway, and R. Tellam. 2005. Lipopolysaccharide and lipoteichoic induce 
different immune responses in bovine mammary epithelial cells. Cytokine 31:72-86.

Travis, J. 1988. Structure, function and control of neutrophil proteinases. Am. J. Med. 84:37-42.

Wedholm, A., H. S. Møller, H. Lindmark-Månsson, M. D. Rasmussen, A. Andrén, and L. B. Larsen. 2008. Identification of peptides in milk as a result of proteolysis at different levels of somatic cell counts using LC MALDI MS/MS detection. J. Dairy Res. 75:76-83.

Windig, J. J., M. P. L. Calus, G. de Jong, and R. F. Veerkamp. 2005. The association between somatic cell count patterns and milk production prior to mastitis. Livest. Prod. Sci. 96:291-299.
Yang, W., H. Zerbe, W. Petzl, R. M. Brunner, J. Günther, C. Draing, S. von Aulock, H. J. Schuberth, and H. M. Seyfert. 2008. Bovine TLR2 and TLR4 properly transduce signals from Staphylococcus aureus and $E$. coli, but $S$. aureus fails to both activate NF- $\kappa \mathrm{B}$ in mammary epithelial cells and to quickly induce TNFa and interleukin-8 (CXCL8) expression in the udder. Mol. Immunol. 45:1385-1397. 